Original Research

\title{
Framework for Valuating Urban Wetland Park Ecosystem Services Based on the Cascade Approach
}

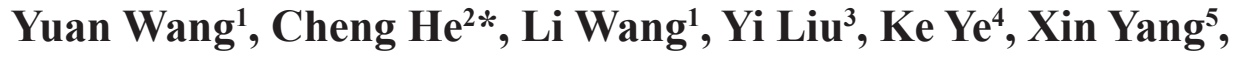 \\ Zhihong Kong ${ }^{6}$, Yijiang $\mathrm{Su}^{6}$ \\ ${ }^{1}$ College of Geography and Tourism, Anhui Normal University, Wuhu, China \\ ${ }^{2}$ Department of Environmental Science and Engineering, Fudan University, Shanghai, China \\ ${ }^{3}$ NEWECO Design Co. Ltd, Shanghai, China \\ ${ }^{4}$ State Key Laboratory of Estuarine and Coast, East China Normal University, Shanghai, China \\ ${ }^{5}$ National Engineering Research Centre of Geo-Spatial Information Technology, Fuzhou University, Fuzhou, China \\ ${ }^{6}$ Management Department of Aha Lake National Wetland, Guiyang, China
}

Received: 24 March 2018

Accepted: 3 June 2018

\begin{abstract}
Urbanization has brought about a substantial increase in population growth, and a considerable amount of park green space has been exposed to urban construction land, which has greatly affected the natural and social value of the urban natural capital. Although this problem is serious in developing countries such as China, few studies have been conducted on the basis of a comprehensive evaluation of urban natural areas. This study evaluates the ecological services value of urban wetland parks from two perspectives: 1) the urban economic development brought by urbanization has an obvious artificial influence on an urban park's economic value and 2) the wetland ecosystem plays an important role in regulating and improving the surrounding urban environment. A flexible evaluation step model and a series of quantitative evaluation methods was constructed and used in a case study of Aha Lake National Wetland Park in Guiyang, China, based on a comprehensive analysis of the social, economic, and ecological values of the park. The results show that the total ecosystem service value of Aha Lake National Wetland Park is $1.92 \times 10^{9}$ yuan. This article has two main purposes: 1 ) serving as an innovative quantitative evaluation method of key indicators and 2) establishing a framework of ecosystem services value evaluation for urban parks based on the cascade model.
\end{abstract}

Keywords: ecosystem services value, cascade approach, urban wetland park

*e-mail: wuygal@163.com 


\section{Introduction}

Wetlands not only provide food, water, and shelter for fish, birds, and other wildlife [1], but also provide important ecosystem services such as water quality improvement, flood abatement, and carbon sequestration [2]. They play an important role in maintaining ecosystem functions. China has established 468 urban wetland parks, and many wetland management agencies include the Ministry of Environmental Protection (MEP), the State Oceanic Administration (SOA), and the Ministry of Agriculture (MA). This reflects the government's attempt to implement a native environment that focuses on natural resources reserves and ecosystems related to regional ecological protection [3]. In recent decades, most of the focus has been on wetland habitat protection and restoration. With the development of society and the economy, the impact of tourism on wetland parks has become obvious. Especially in urban areas, the increase in the number of tourists has brought more intense man-made coercion to the park ecosystem, and also enhances the service value of the park. Much research has started to pay attention to the ecosystem value of wetlands, and the primary goal of this study is to assess ecosystem services from the perspective of comprehensive socio-economic and natural environment [4-6].

The value of ecosystem services refers to the value that ecosystems bring directly or indirectly to human society $[7,8]$. For urban wetland parks the service value of ecosystems is special and affected by two aspects: 1) the ecological value of the wetland ecosystem, such as adjusted functions and support functions, and 2) the close connection between the park and the city, such as the economic activities of surrounding urban areas and the surrounding residents, will interact with the park's ecological environment and eventually affect the socioeconomic value of the park's ecosystem [9]. In addition to the ecosystem environment, attention should also be paid to the socio-economic background of the park and the impact of socio-economic activities on the ecosystem value of parks in the case of urban wetland parks. However, in existing research, few studies reflect both in a value evaluation.

The ES (ecosystem service) cascade model is a comprehensive and intuitive model that can completely display the complete process of ES function evaluation and help to understand the mechanisms that link ecological systems to human well-being $[10,11]$. And it provides a methodological system that takes ecosystem structure and processes into consideration, linking all the benefits and social and economic values that ecosystems can deliver. This model consists of 5 steps:

1) Determine the study area and analyze the main structure and characteristics of the ecosystem.

2) Based on the analysis of ecosystem characteristics and the definition of functional value [10], select the main ecosystem functions.
3) Regarding the regulation of floods and reducing environmental pollution, etc., sorting out the service value provided by the ecosystem.

4) Starting from the definition of contributing to human health and safety, summarizing the various benefits provided by the ecosystem.

5) Determining what social and economic values are attributed to the ecosystem benefits $[12,13]$.

Many studies are based on this theory for organizing the evaluation ecosystem values [14-16]. However, there is little research on urban parks. Based on the existing research framework, it is difficult to reflect on the natural role of wetland ecosystems and the social characteristics of urban parks at the same time, because the urban economic function of some parts of the park is not obtained starting from the park ecosystem. It is necessary to adjust the model structure for urban areas.

Compared with the current ES evaluation for wetland parks, which are mostly based on natural resources and environmental impact analyses [17-19], this study aims to construct a corresponding evaluation system around the complex features of urban parks. The main research content of this study includes two aspects:

1) On the theoretical level, based on the characteristic analysis of the urban park's ecological environment, trying to optimize the ES cascade mode and reflect characteristics through different components while trying to make the evaluation process not only reflect complex socio-economic impact of the city but also reflect the characteristics of its own ecological environment.

2) On a practical level, combining with the methods of remote sensing technology, ecosystem process model, and socioeconomic numerical statistics, our paper tries to innovate the quantitative evaluation method of some key factors, thus enriching the quantification methods and making the evaluation results objective.

Our aim is to provide a set of methodological frameworks that emphasize the practical. More importantly, we try to explore the relationship between ES evaluation and park planning management based on the evaluation results, making wetland park managers respond to the challenges of future urbanization and helping to make decisions between ecological environment protection and sustainable development.

\section{Material and Methods}

\section{The Research Area}

As the capital city of Guizhou province in China, Guiyang has a total area of 8,034 square kilometers. Because of the excellent native ecological environment in the urban area, the overall urban forest coverage rate has reached $40 \%$. With the rapid development of the urban economy, the population has rapidly 

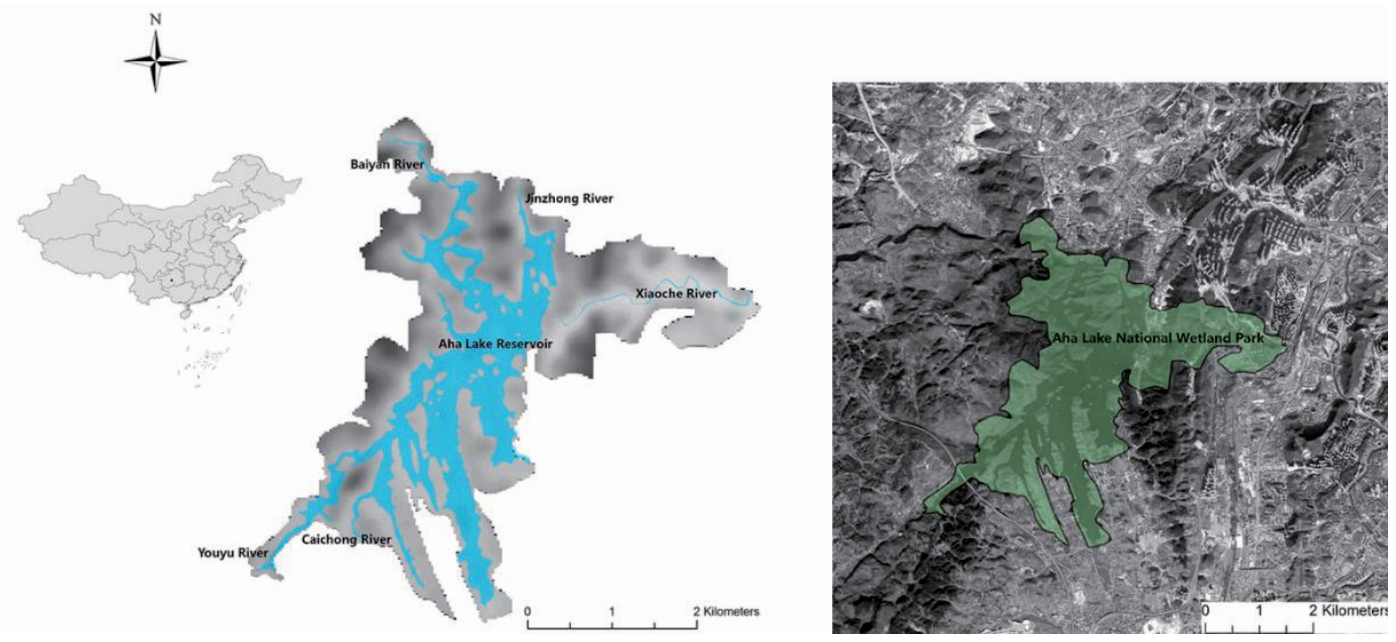

Fig. 1. Location of Aha Lake National Wetland Park in China and the Spatial distribution in Guiyang (left); Aha Lake reservoir and the main water system in the park (right).

increased from 3.1 million in 2001 to 4.7 million in 2015. To promote sustainable development and meet the urban residents' requirements for urban ecological environments, the Guiyang government recently proposed the goal of "Building a city with thousands of parks," which would raise the urban forest coverage rate into more than $50 \%$ in 2020 . Therefore, how to balance the relationship between the development of various kinds of urban parks and the protection of urban ecosystems becomes an important research content of urban development.

The coordinates of the Aha Lake National Wetland Park range from $106^{\circ} 36^{\prime} 59^{\prime \prime E}-106^{\circ} 40^{\prime} 44^{\prime \prime} \mathrm{E}$ and $26^{\circ}$ $30^{\prime} 40^{\prime \prime} \mathrm{N}-26^{\circ} 33^{\prime} 55^{\prime} \mathrm{N}$. The park is about $6.5 \mathrm{~km}$ wide from south to north and $6 \mathrm{~km}$ wide from east to west with total area of 1218 hectares. The range includes Aha Reservoir, the lower reaches and its estuary of the Youyu River, Jinzhong River, and Baiyan River, the estuary of the Lanjigou, the estuary of the Caichong River, as well as the first heavy mountain surrounded by Aha.

Among them, the main body of Aha Lake Wetland Park is Aha Reservoir, which is a medium-sized reservoir dominated by urban water supply and flood control that intercepts incoming water from the upper reaches of the Xiaoche River in the tributary of the Nanming River in flood season to ease flood control pressure in the urban area. At the same time, it is also the main source of water for urban residents in Guiyang. With the process of urbanization, the wetland park and its surrounding residents are getting closer and closer together. In 2013 the park received more than 3 million tourists. From these characteristics, this study chooses Aha Lake Wetland Park as the research object.

\section{Framework of the Method}

The main objective of this research is to construct a system of ecosystem service value evaluation for urban wetland parks through the application and adjustment of theory model, selecting and innovating various quantitative evaluation models so that the final evaluation results can both reflect the original wetland's natural value, but also reflect the social and economic characteristics of an urban park.

Due to the particularity of the original wetland environment and the complexity of socio-economic relationship in urban wetland park, this study chose the step models by Haines-Young and Potschin [20], and based on this theoretical model we made some adjustments. Fig. 2 shows the workflow we finally applied for assessing the ES in urban wetland park. The starting point of ES assessment is understanding and analyzing the "structure and process of the regional ecosystem." It is the same with the beginning of the cascade model that is mainly based on the study of natural elements. Through this step, the components of the ecosystem function are divided. The definition of "ecosystem function" in the cascade model is "the elements or functions of ecosystem component and processes that provide service directly" [10]. Based on this definition, starting with "providing services directly," this step chooses and quantifies the function index from the aspects of "support" and "adjustment." The next step of the workflow is economic and social benefits, to sum up the socioeconomic value of the study area as an urban park, following the definition of the benefits in the economics of ecosystems and biodiversity (TEEB) cascade, which is "the positive change in wellbeing from the fulfillment of needs and wants" [13], we divide the value of this part into two: 1) The most obvious socioeconomic value for urban parks is the recreation function. 2. The surrounding residents' willingness to pay for the park's environment would reflect the socio-economic significance of the park to the surrounding area. In the final step, the results of all the quantitative values are added.

In contrast to the TEEB cascade we've incorporated "service" and "benefits," and do not include "supply" 


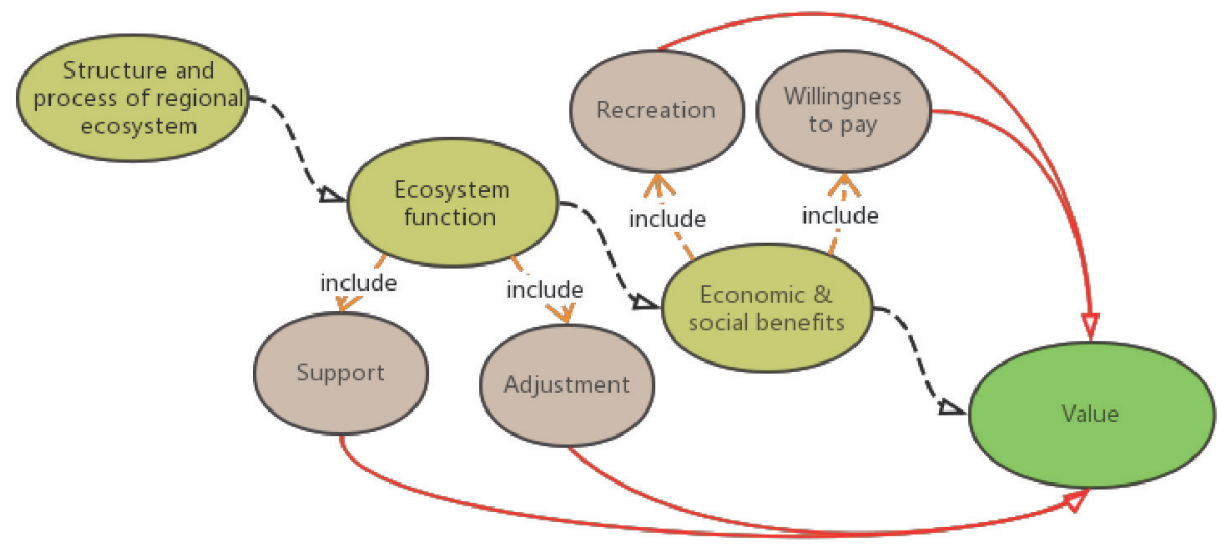

Fig. 2. Workflow of assessing ES value for urban wetland park based on the cascade model of [10].

service [10]. Because the main purpose of this study is value evaluation, service is directly reflected in the selection of functional values, and the "service" is covered in "function" analysis. In an urban park, the main function is to provide entertainment for urban residents; the production function of the ecosystem is not the main functional content, so the production service value and other agriculture-related values were ignored. The adjustment made in this study is mainly to show the value of urban parks as an additional element between ecosystem and social system. The purpose of integrating and leaving these two steps of "structure and process of regional ecosystem" and "economic and social benefits" is to show that ES of urban park values are derived from ecosystem functions and lead to benefits for humans from the aspects of urban environment and social, which is not stressed through the TEEB model.

The ES valued monetarily in this study is mainly from two perspectives: replacement cost and willingness to pay. On the other hand, some non-monetary ecological environmental indexes were quantified by means of a model. And then evaluated by means of replacement cost. Following the defined ES, "the benefits that humans derive from ecosystems" [13, 21]. The value of the wetland park is expressing the importance of an urban park as regards nature or socially [21].

\section{Results}

\section{Structure and Process of Regional Ecosystem}

The park covers a wide area of which the ecosystem is complex and diverse, including a large-scale water reservoir and native wetlands. The structures and processes of park ecosystems are mainly reflected in the following two aspects:

1) The complexity of the park's internal environment. The Aha Lake Wetland Park covers large reservoirs and includes various types of ecosystems as wetland

Table 1. Internal structure and process components of the ecosystem-to-ecosystem functions and their quantified indicators at Aha Lake National Park.

\begin{tabular}{|c|c|c|}
\hline $\begin{array}{l}\text { Structure and process } \\
\text { of regional ecosystem }\end{array}$ & Ecosystem Function & Functional indicator \\
\hline Water & The reservoir provides fresh water for the city daily production and daily life & Water support ${ }^{1}$ \\
\hline \multirow{3}{*}{ Vegetation } & $\begin{array}{l}\text { The vegetation inside wetland ecosystems can absorb carbon dioxide effec- } \\
\text { tively [22] }\end{array}$ & Carbon fixation ${ }^{2}$ \\
\hline & $\begin{array}{l}\text { Vegetation and surface fresh water enables the wetland ecosystem to release } \\
\text { large amounts of oxygen[23] }\end{array}$ & Oxygen release $^{2}$ \\
\hline & Adjust the temperature[24] & Temperature modulation ${ }^{2}$ \\
\hline \multirow{3}{*}{$\begin{array}{l}\text { Soil and ground } \\
\text { surface }\end{array}$} & $\begin{array}{l}\text { Root absorption and natural soil water storage makes the wetland has the } \\
\text { function of regulating floods[25] }\end{array}$ & Regulate floods ${ }^{2}$ \\
\hline & Purify the water[26] & Water purification $^{2}$ \\
\hline & Fertilizer conservation and soil reinforcement [27] & $\begin{array}{l}\text { Soil reinforcement }{ }^{2} \\
\text { Fertilizer conservation }\end{array}$ \\
\hline
\end{tabular}

1. "adjustment" ecosystem function

2. "support" ecosystem function 
Table 2. Socio-economic benefits and their quantified indicators at Aha Lake National Park.

\begin{tabular}{|c|c|c|}
\hline Socio-economic benefits & Benefits & Benefit indicators \\
\hline Direct economic benefit & $\begin{array}{c}\text { The ecological environment's most direct function is recreation, through } \\
\text { the payment for recreation by park visitors, ecological functions generate } \\
\text { socio-economic value directly. }\end{array}$ & Recreation \\
\hline Indirect social benefit & $\begin{array}{c}\text { The surrounding urban residents enjoyed the direct ecological value brought } \\
\text { by the park. The willingness to pay can reflect the value provided by } \\
\text { the surrounding residents to the park construction. }\end{array}$ & $\begin{array}{c}\text { Willingness to pay for } \\
\text { ecosystem functions }\end{array}$ \\
\hline
\end{tabular}

parks. Ecosystem valuation of this region would involve many different ecological environment factors. According to the workflow of this research (Fig. 2), first analyzing the internal structure and process components of the ecosystem in the park from several important perspectives, wummarizing the ecosystem functions from these perspectives, and determining the quantitative evaluation of different functions from the aspects of "adjustment" and "support." The analysis process of this section is shown in Table 1.

2) The complexity of the park's surrounding environment. In recent years, with the acceleration of urbanization in the surrounding urban areas, the number of tourists in the park has risen and the manmade surface area of the surrounding areas has been continuously increasing. All aspects of the park and the city's social economy becomes closer, thereby improving the park's socio-economic value. The value of this part is manifested when the ecosystem function is related to the surrounding socio-economic factors, and according to the research workflow (Fig. 2), the economic and social benefits are studied from the ecosystem function of this park. And based on related research on the value of wetland parks [28], the study divides the benefits into two: direct economic benefit and indirect social benefit. The analysis process is shown in Table 2 .

\section{Ecosystem Function}

According to the research framework, this part divides the evaluation index into two categories: "support" and "adjustment." The functional evaluation index were chosen from the main ecological components that make up the wetland ecosystem. In the case of Aha Lake Park, we selected the environmental elements that have a great impact on the surrounding ecological environment: water, soil, vegetation.

\section{Support}

As a city park, a major feature of the study area is its huge reservoir, and the results of perennial water reservoirs showed that the average annual runoff of the five inflow tributaries reached 102 million $\mathrm{m}^{3}$. According to data provided by Aha Lake Reservoir Management, the park's reservoirs can supply up to $5 \times 10^{7} \mathrm{~m}^{3}$ of water per year to urban waterworks. So, providing a highquality water reservoir is the most prominent support function value of this park, the quantitative evaluation formula is as follows:

$$
V=C \times L
$$

$\mathrm{V}$ represents the overall quality of the reservoir water support function value and $\mathrm{C}$ is local tap water prices. The local water price is $2.7 \mathrm{RMB} / \mathrm{t}$ at Guiyang, $\mathrm{L}$ is the reservoir annual water support, and the results show that the total value of water support function value in Aha Lake National Wetland Park is $1.35 \times 10^{8} \mathrm{RMB} / \mathrm{a}$.

\section{Adjustment}

\section{Carbon Fixation}

Large-scale production and living make the city a huge carbon source, and an urban wetland park is of great significance for regulating the carbon cycle in an urban area [29]. To measure this part of the value, this study introduced the measure of net primary productivity (NPP) at park scale [30, 31], which is an important indicator to determine the size of vegetation productivity, measure the ability of ecosystem carbon sequestration, and regulate ecological processes.

The Carnegie Ames Stanford approach (CASA), founded by Potter in 1993, is the most commonly used remote sensing model for quantitative inversion of NPP in current research and applications [32]. The principle is based on:

$$
\begin{gathered}
N P P(x, t)=S(x, t) \times \operatorname{FPAR}(x, t) \times 0.5 \times \varepsilon(x, t) \\
\varepsilon(x, t)=T_{\varepsilon 1}(x, t) \times T_{\varepsilon 2}(x, t) \times W_{\varepsilon}(x, t) \times \varepsilon_{\text {max }}
\end{gathered}
$$

...where $\mathrm{x}$ represents space location, $\mathrm{t}$ represents time, $\mathrm{S}$ represents total solar radiation $\left(\mathrm{MJ} / \mathrm{m}^{2} / \mathrm{month}\right)$, FPAR indicates the proportion of vegetation absorbed by the incident photosynthetic active radiation, 0.5 represents the ratio of solar radiation absorbed by vegetation to total solar radiation, $\mathrm{T}_{\varepsilon 1}(\mathrm{x}, \mathrm{t})$ and $\mathrm{T}_{\varepsilon 2}(\mathrm{x}, \mathrm{t})$ are the stress effects of light energy utilization at low temperature and high temperature (respectively), and $\mathrm{W}_{\varepsilon}(\mathrm{x}, \mathrm{t})$ is moisture stress influence coefficient. The calculation of the above 


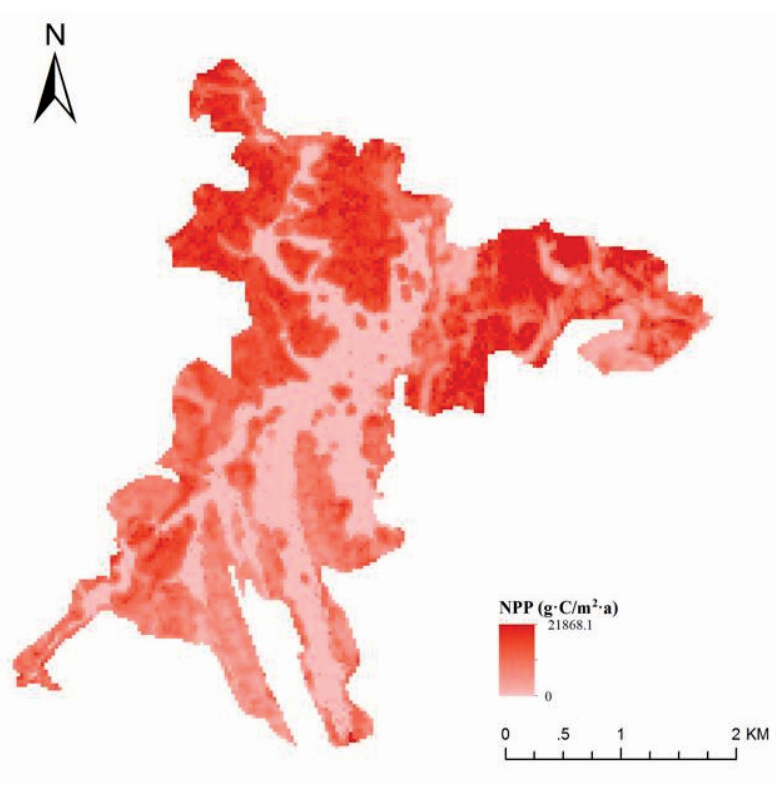

Fig. 3. Spatial distribution of the NPP index in the study area.

four values mainly use the research results of Zhu [33]. $\varepsilon_{\max }$ is the maximum light energy utilization under ideal conditions. Different types of vegetation correspond to different values, in this study using the research results of Running and Potter [32]. The values of FPAR and NDVI have a certain linear relationship that can be determined by calculating the maximum and minimum NDVI of different types of vegetation [34]. The NDVI value is calculated based on the Landsat data of April 13, 2017. The calculation of $S$ and $\varepsilon$ uses the relevant methods in the study of Zhu, and the calculation process involves the meteorological value of precipitation, temperature, and solar radiation in the study area, mainly from the observation data of meteorological stations in the park.

The obtained NPP space distribution results are shown in Fig. 3. The average NPP in the park is $204.55 \mathrm{gC} / \mathrm{m}^{2} \mathrm{a}$, the total carbon sequestration in the park is $2.49 \times 10^{9} \mathrm{gC}$, the market value of carbon is $\$ 43 \mathrm{US}$, and through conversion the total value of park carbon fixation is $7.21 \times 10^{5} \mathrm{RMB}$.

\section{Oxygen Release}

In addition to carbon sequestration, wetland vegetation also has the function of releasing oxygen, which plays an important role in improving the atmospheric environment in the surrounding cities of the park. The amount of oxygen released is calculated based on the plant photosynthesis equation, which states that vegetation releases 1.19 grams of oxygen per gram of dry matter produced [35], and then through the equivalent replacement method to calculate the market value of oxygen release. The amount of dry matter produced can be calculated by the amount of NPP, which is $2.49 \times 10^{9} \mathrm{~g}$. By conversion, the market value of this part is:
$\mathrm{V}=2.49 \times 10^{9} \times 1.19 \times 1000 / 1000000=2.96 \times 10^{6} \mathrm{RMB}$

\section{Temperature Modulation}

In addition to releasing oxygen, the park's ecosystem improves the surrounding atmosphere with temperature regulation. Due to the huge heat capacity of urban wetlands and the strong evaporation of water in the reservoir, it has obvious cooling and humidifying effects on the surrounding urban climate, which is assessed through temperature contrasts both inside and outside the park. The formula is as follows:

$$
V=c \cdot p \cdot C \cdot S \cdot H \cdot(Q d \times D d+Q i \times D i) .
$$

...where $\mathrm{V}$ represents the overall value of wetland temperature modulation; $c$ represents the specific heat capacity of air, and its value is $1030 \mathrm{~J} /\left(\mathrm{kg} \cdot{ }^{\circ} \mathrm{C}\right) ; \rho$ is air density, with a value of $1.29 \mathrm{~kg} / \mathrm{m}^{3} ; \mathrm{C}$ is the local electricity price $(0.510 \mathrm{RMB} / \mathrm{kWh})$; $\mathrm{S}$ is the total area for temperature regulation of wetlands $\left(1218 \mathrm{hm}^{2}\right)$; $\mathrm{H}$ represents the height difference of temperature regulated by the park ecosystem, measured by the DEM data and with a value of $0.0024 \mathrm{~km}$; and Qd is the average daily temperature drop of wetlands in summer. The data are obtained by comparing the observed air temperature in the wetland park and the average temperature in Guiyang. The average value is $2.58^{\circ} \mathrm{C}$ in summer. $\mathrm{Dd}$ is the number of summer days, according to the annual statistics of monthly record data from the Guiyang Statistical Yearbook. Taking 70 days in this study, Qi is the average daily temperature rise of wetlands in winter, for which the value is $2.47^{\circ} \mathrm{C}$; $\mathrm{Di}$ is the number of days in winter, taking 60 days in this study. The total value of $\mathrm{V}$ is $1.81 \times 10^{6} \mathrm{RMB}$.

\section{Regulate Floods}

This ecosystem not only provides important water sources for the surrounding residents, but also regulates floods, which is one of the important functions of a wetland ecosystem [36]. The value of regulation function is mainly based on perennial observed water storage and storage capacity, and the formula is:

$$
V=L \times M
$$

...where $\mathrm{V}$ represents the overall flood control value of Aha Lake Reservoir; L is the total reservoir water storage capacity $\left(\mathrm{m}^{3}\right)$ - storage capacity of the reservoir is 72 million $\mathrm{m}^{3}$; and $\mathrm{M}$ is the cost of reservoir storage capacity, which in this study was settled at $1.81 \mathrm{RMB} / \mathrm{m}^{3}$. Based on the national statistical data, the average reservoir storage cost in China was $0.67 \mathrm{RMB} / \mathrm{m}^{3}$ in the $1990 \mathrm{~s}$. By using the annual change rate of the national fixed asset investment price index we can conclude that the cost of reservoirs in 2016 is $1.81 \mathrm{RMB} / \mathrm{m}^{3}$. Through formula 1.5 , the total value of this part is $1.30 \times 10^{8} \mathrm{RMB}$. 


\section{Water Purification}

Another important function of the reservoir is water purification. There is a certain degree of agricultural production and daily water discharge activities surrounding the park, causing pollution and eutrophication of surrounding water bodies, among which is COD (chemical oxygen demand: the oxygen equivalent of the substance that can be oxidized by a strong oxidizing agent), which is the indicator that can represent water body pollution, TN (total nitrogen: representing milligrams of nitrogen per liter of water), and TP (total phosphorus: representing milligrams of nitrogen per liter of water) - which are the indicators that represent water body eutrophication. In response to this man-made water stress, wetland ecosystems can filter out contaminants in water through watersoil-biological complex systems to achieve the function of water purification [37], the value evaluation of this function is mainly based on the COD, TN, and TP:

$$
V=\sum\left(N_{i} \times R_{i} \times P_{i}\right)_{i \in(C O D, T N, T P)}
$$

...where $\mathrm{V}$ is the total water purification value of the reservoir; $\mathrm{N}$ represents the total amount of pollutants - the total amount of TP removal in Aha Reservoir is $8750 \mathrm{~kg}$ and the removal of TN is $298300 \mathrm{~kg}$, and because of the lack of removal rate data for COD, this study calculated the retention of COD at $10840000 \mathrm{~kg}$; and $\mathrm{R}$ represents pollutant removal rate (\%). According to the regional removal rate provided by the local environmental protection bureau in Guiyang, the removal rates of $\mathrm{TN}$ and $\mathrm{TP}$ are $35.5 \%$ and $24.4 \%$; and $\mathrm{P}$ is the average cost of cleaning up per unit pollutants $(\mathrm{RMB} / \mathrm{kg})$. According to the average observational values provided by park managers, it takes 1.5 for $\mathrm{TN}$, 2.5 for TP, and 1.6 for COD. Through the formula and combined with the market price cost of pollutant removal, the final purification value of TP was calculated as $5337.5 \mathrm{RMB}$, the purification value of $\mathrm{TN}$ is $1.60 \times 10^{5}$ $\mathrm{RMB}$, and the COD purification value was $1.73 \times 10^{7}$ RMB. The final amount of purified water is worth a total of $1.75 \times 10^{7} \mathrm{RMB} / \mathrm{a}$.

\section{Soil Reinforcement}

The function of soil reinforcement is mainly through the plants in the ecosystem [38]. Therefore, this value assessment is mainly used for the park's vegetation cover. And the calculation of soil reinforcement volume is mainly according to the following formula:

$$
G=Q-Q^{\prime}=\left[d \times \frac{S}{5.1 \%}-d \times S\right] \times 10^{6}
$$

...where $\mathrm{G}$ is on behalf of the total soil reinforcement at Aha Lake Park; Q represents the total potential soil erosion in forest area $(\mathrm{g} / \mathrm{a})$; Q' stands for the total actual soil erosion in forest area $(\mathrm{g} / \mathrm{a}) ; d$ represents the actual soil erosion modulus $\left(\mathrm{t} /\left(\mathrm{hm}^{2} \cdot \mathrm{a}\right)\right)$; and $\mathrm{S}$ is the total vegetation area of this park $\left(\mathrm{hm}^{2}\right)$. In this study, the values of $\mathrm{d}$ applied the actual soil erosion modulus of subtropical evergreen broad-leaved forest, which is $3.20 \mathrm{t} /\left(\mathrm{hm}^{2} \bullet \mathrm{a}\right)$. On the other hand, this study used Landsat 8 data (April 13, 2017), through the method of land use type interpretation to get the value of $\mathrm{S}$. The calculated results show that the total annual soil reinforcement in Aha Lake National Wetland Park is $2.98 \times 10^{10} \mathrm{~g}$.

After getting the total, according to the method of energy analysis, the goal of this part is to convert the total amount of soil reinforcement into market value. According to the energy conversion ratio of the soil surface layer, which is $67800 \mathrm{~J} / \mathrm{g}$, the total energy of soil reinforcement in the park is $2.02 \times 10^{15} \mathrm{~J}$. And based on the energy conversion rate of solid reinforcement $\left(7.40 \times 10^{4}\right)$, which calculates the solar value at $1.49 \times 10^{20} \mathrm{sej} / \mathrm{a}$, multiplied by the value of the currency ratio, the energy value is $1.37 \times 10^{8} \mathrm{RMB} / \mathrm{a}$ - finally, that is, the amount of solid reinforcement of this park is $1.37 \times 10^{8} \mathrm{RMB} / \mathrm{a}$.

\section{Fertilizer Conservation}

Soil is an important part of the park's ecosystem, and fertilizer conservation is another important ecological value of the soil in addition to soil reinforcement. For the evaluation of this part of the function this study used the following formula:

$$
V_{m}=G \times H m .
$$

...where $\mathrm{V}_{\mathrm{m}}$ represents the loss of $\mathrm{N}, \mathrm{P}$, and $\mathrm{K}$ nutrients in soil caused by the decrease of vegetation $(\mathrm{g} / \mathrm{a})$; $\mathrm{G}$ is the total amount of soil reinforcement, which is calculated through formula 1.7; $\mathrm{Hm}$ stands for the content (\%) of $\mathrm{N}, \mathrm{P}$, and $\mathrm{K}$ in soil, with average observational values provided by park managers of the three being, respectively, $0.418,0.089$, and 0.181 ; according to formula 1.8, the corresponding three kinds of nutrients are saved as follows:

$$
\mathrm{V}_{\mathrm{N}}=1.25 \times 10^{10} \mathrm{~g} ; \mathrm{Vp}=2.65 \times 10^{9} \mathrm{~g} ; \mathrm{V}_{\mathrm{K}}=5.39 \times 10^{9} \mathrm{~g} .
$$

According to $\mathrm{N}, \mathrm{P}, \mathrm{K}$ energy conversion rate $\left(4.62 \times 10^{9} ; 6.88 \times 10^{9} ; 2.96 \times 10^{9}\right)$, the solar energy values corresponding to the above three indexes are respectively $5.78 \times 10^{19} \mathrm{sej} / \mathrm{a} ; 1.82 \times 10^{19} \mathrm{sej} / \mathrm{a}$; $1.60 \times 10^{19} \mathrm{sej} / \mathrm{a}$, and then calculate the value of the monetary value (RMB/a) according to the exchange rate of $1.09 \times 10^{12}$. The corresponding value of the three values are: $5.30 \times 10^{7} \mathrm{RMB} / \mathrm{a} ; 1.67 \times 10^{7} \mathrm{RMB} / \mathrm{a}$; $1.47 \times 10^{7} \mathrm{RMB} / \mathrm{a}$, The sum of the three is $8.44 \times 10^{7} \mathrm{RMB} / \mathrm{a}$, so the total value of fertilizer conservation in this park is $8.44 \times 10^{7} \mathrm{RMB} / \mathrm{a}$.

\section{Economic and Social Benefits}

This section mainly measures the social value of the study area as an urban park, reflected in two aspects: 
Table 3. Energy conservation analysis of fertilizer conservation in Aha Lake National Wetland.

\begin{tabular}{|c|c|c|c|c|}
\hline Index & $\begin{array}{l}\text { Weight } \\
(\mathrm{g} / \mathrm{a})\end{array}$ & $\begin{array}{c}\text { Energy } \\
\text { conversion } \\
\text { rate }\end{array}$ & $\begin{array}{l}\text { Energy values } \\
\text { (sej/a) }\end{array}$ & $\begin{array}{c}\text { Market } \\
\text { value } \\
(\mathrm{RMB} / \mathrm{a})\end{array}$ \\
\hline $\mathrm{N}$ & $1.25 \times 10^{10}$ & $4.62 \times 10^{9}$ & $5.78 \times 10^{19}$ & $5.30 \times 10^{7}$ \\
\hline$P$ & $2.65 \times 10^{9}$ & $6.88 \times 10^{9}$ & $1.82 \times 10^{19}$ & $1.67 \times 10^{7}$ \\
\hline K & $5.39 \times 10^{9}$ & $2.96 \times 10^{9}$ & $1.60 \times 10^{19}$ & $1.47 \times 10^{7}$ \\
\hline \multicolumn{4}{|c|}{ Sum up } & $8.44 \times 10^{7}$ \\
\hline
\end{tabular}

\section{Recreation}

In addition to the supportive and regulatory functions provided, the positive effects of the natural environment on human physiology have drawn increasing attention from researchers. The natural environment and the time consumed in these natural environments can relax people's nervousness by forming psychological person-place ties. It has been found that the perception of the natural state can enhance its cognition of physical activity and self-awareness. The sense of well-being here includes all aspects of physical status and social psychology. This study summarizes the value of this part as a recreational function and uses the travel cost interval method (TCM) to calculate the recreational value of Aha Lake Wetland Park [39], including travel expenses, travel time value, and consumer surplus:

$$
\begin{gathered}
C=W+V_{(t)}+S C_{i} \quad 1.9 \\
V_{(t)}=0.33 \times D \times \frac{Y}{30} \\
S C_{i}=\int_{C_{i}}^{\infty} Q(C) d C
\end{gathered}
$$

...where $\mathrm{C}$ is the total actual cost of tourists' travel, $\mathrm{W}$ on behalf of travel expenses, including tickets, accommodation, fares, group fees and shopping, etc., $\mathrm{V}_{(t)}$ is the value of travel time, $\mathrm{D}$ is the time for tourists to travel, $\mathrm{Y}$ is the monthly salary of tourists, $\mathrm{SC}_{\mathrm{i}}$ is the consumer surplus value, $\mathrm{Q}(\mathrm{C})$ is the tourist demand curve for tourists calculated, and $i$ is the consumer surplus value of tourists' corresponding to the $i$ interval (based on the statistical results of the questionnaire). $\mathrm{W}_{\text {per capita }}=42.8 \mathrm{RMB}$ and $\mathrm{V}_{\text {per capita }}=119.5 \mathrm{RMB}, \mathrm{Q}(\mathrm{C})$ is obtained by exponential fitting of travel expenses (W) and travel consumption intention $(\mathrm{Q}(\mathrm{C}))$, the result is shown in the formula 12 , and $\mathrm{R}^{2}$ is 0.9274 :

$$
\mathrm{Q}(\mathrm{C})=e^{0.4617-0.0004 w}
$$

According to the statistics provided by the park manager, the number of park visitors in 2015 was 3.1 million, and the total value of recreation is $1.38 \times 10^{9}$ RMB.
2. Willingness to pay for ecosystem function.

In addition to the recreational function, the economic and social benefits of the urban park is also reflected in the willingness to pay for park ecosystem function from the surrounding residents. This value can be reflected by way of social surveys. This part of the evaluation using conditional value method (CVM), which was proposed by Davis in 1963 [40], mainly measures the value of non-market items. At present, the method has been widely used to analyze the correlation between socio-economic factors and ecosystem services [41], the formula is as follows:

$$
T_{W T P}=M W T P \times R_{W T P} \times N
$$

...where $\mathrm{T}_{\mathrm{WTP}}$ represents the value of willingness to pay, MWTP represents the mean willingness to pay, $R_{\text {wTP }}$ is the positive payout ratio, and $\mathrm{N}$ is the actual number of people willing to pay. In this study, 300 questionnaires were distributed and 292 valid questionnaires were returned, including 190 from Guiyang and 102 from other parts of Guizhou. In the valid questionnaire data, the cumulative frequency of the nearest $50 \%$ is $41.18 \%$ and $57.47 \%$, the corresponding WTP were 5-10 RMB and 10-20 RMB, and then take the median 7.5 RMB and $15 \mathrm{RMB}$ as the representative. The median cumulative frequency obtained by linear interpolation is $11.56 \mathrm{RMB}$, so the mean willingness to pay is 11.56 RMB. The positive payout ratio is $66.22 \%$, and $\mathrm{N}$ uses the population of Guiyang, then calculated through formula 1.10 , and the value of this function was $3.60 \times 10^{7}$ RMB.

\section{Values}

By definition, total value describes the value of ecosystem for humans as the sum of components [21]. In this study, we considered the actual use value that an ecosystem has for the local resident around the park, based on the structure and process of regional ecosystem, the total value of the park is measured by selecting various indicators from the steps of ecosystem function and socio-economic benefits.

Among the various steps, despite the method employed, the most important ecosystem services were "Recreation," which reflects the man-made coercion faced by the park. However, there is a variation between the values of individual ES depending on the method. The ecosystem characteristics are considered in the calculation of each step. In general, the estimated values at the park follow the analysis of the total structure and process of a regional ecosystem.

\section{Discussion}

The main content of this study draws on the research framework of ecosystem services functional value evaluation, and evaluating all kinds of natural and social 
Table 4. Total value for ecosystems in Aha Lake National Wetland Park.

\begin{tabular}{|c|c|c|c|}
\hline Steps & Aspects & Indicators & Value (RMB) \\
\hline \multirow{8}{*}{ Ecosystem function } & Support & Water support & $1.35 \times 10^{8}$ \\
\hline & \multirow{7}{*}{ Adjustment } & Carbon fixation & $7.21 \times 10^{5}$ \\
\hline & & Oxygen release & $2.96 \times 10^{6}$ \\
\hline & & Temperature modulation & $1.81 \times 10^{6}$ \\
\hline & & Regulate floods & $1.30 \times 10^{8}$ \\
\hline & & Water purification & $1.75 \times 10^{7}$ \\
\hline & & Soil reinforcement & $1.37 \times 10^{8}$ \\
\hline & & Fertilizer conservation & $8.44 \times 10^{7}$ \\
\hline \multirow{3}{*}{ Socio-economic benefits } & Recreation & Travel cost & $1.38 \times 10^{9}$ \\
\hline & \multirow{2}{*}{ Willingness to pay } & Willingness to pay for ecosystem function & $3.60 \times 10^{7}$ \\
\hline & & Total value & $1.92 \times 10^{9}$ \\
\hline
\end{tabular}

values that can represent the characteristics of urban wetland parks. The values involved in the evaluation not only include the function value directly provided by the elements of the park environment, but also from the resulting the impact of these components. The purpose of this study is to convert all kinds of ecosystem service functions into corresponding market values on a park scale and accumulate the values provided by various functions to obtain the overall ecosystem service value of wetland parks.

Objectively speaking, for the same wetland park, a series of different indicators can be used to evaluate. In the case of Aha Lake Wetland Park, as an urban wetland park with an annual flow of more than 1 million people, many functions and their economic impacts are not considered in this study. For example: the value of various rare species in the park [42] - especially the wide range of wetland birds - and rare vegetation in the park. In view of these circumstances. the relevance of a common scale can be questioned. The existing research shows that there are many kinds of values related to a wetland ecosystem $[43,44]$. Because of the different characteristics of different types of wetlands and their relationships with the surrounding natural and social environments, there are many differences in the functions of ecosystem services. Due to the different functions of the wetland park, the evaluation process will have a huge impact on the evaluation results. Therefore, before the evaluation it is very important to analyze the service characteristics of the research area, and then adjust the research framework. This compensatory adjustment can be made by applying the effecting factors that make the effect estimates both convenient and generically applicable as in the standard in the wetland park.

In the process of specific evaluation, in order to reflect the properties of reservoir-type wetlands and meet the socio-economic characteristics of urban parks, the research adjusted the framework: taking into account the characteristics of urban parks, merging the "benefit" and "service" steps, and screening the functional indexes from the important natural elements of wetland parks. After adjustment, the model calculates different values from the three steps of "structure and process of regional ecosystem," "ecosystem function," and "economic and social benefits." The index selection process in each step also reflects the attributes of urban parks and the natural characteristics of reservoir wetlands. The "biophysical structures and processes" step measures the social value of the park from its urban properties. The "ecosystem function" step starts from the natural attributes of a wetland park and measures the natural value of the park through the function of several natural elements. The "economic and social benefits" step, starting from the park's entertainment function, measures the economic value of the park. The research process provides an operational, adjustable, and usable framework for evaluating park ecosystem services.

Although the research goal is to quantify the ecological functions of these parks, some of the quantitative results are still relative. In order to reduce the relativity, this study attempts to convert all kinds of values into market values, because the market value is an objective reference, a unified objective standard can reduce the uncertainty of the evaluation results and directly provide a scientific basis for the future planning of the park and the maintenance of the wetland environment. In general, the model framework of this study can also be regarded as a relatively independent model, which can be adjusted and applied based on the characteristics of other wetland types.

The results show that it is feasible to evaluate different types of value quantitatively, and the importance of different park functions can be reflected by the market value. However, some research has shown that the relationship between various functions is very complex and not isolated in reality. Synergistic and 
conflicting effects may exist between various functions that currently prohibit such estimates. The evaluation process in this study is one-dimensional and does not analyze the interrelationships among various indicators. The relationship between various indicators and the spatial layout of parks and social values has not been explained in our study. Research on the relationship between various ecological functions, such as the complex relationship between human activities and natural environment factors, is an important research direction in the future. If the relationship between these indicators can be quantified, the scientific nature of the evaluation will be enhanced. Policymakers can intuitively grasp the synergies between various planning scenarios and environmental elements, which can co-ordinate all kinds of values and ultimately guide the planning of the park. On the other hand, in this functional assessment, we have considered only the positive impacts from wetland ecosystems, but there are also negative natural and social impacts. For example, the increasingly intensive anthropogenic activities in the park due to its own environment and park construction bring more intense artificial stress to the surrounding native ecosystem [45]. Therefore, partial negative impacts should be considered if we are to consider the full value of ecosystem services.

These two points are also the important directions for the future evaluation of ecosystem function: Quantify the interaction between various types of ecosystem services and evaluate the negative effects from different degrees of ecosystem. Comprehensively explore how urban parks can cope with all aspects from future urbanization.

In addition, the relationship between ES value and park planning is very important. In the process of pre-planning, a general park will face the spatial layout under different planning scenarios, and some environmental function factors have obvious differences under different planning spatial layouts (such as carbon fixation, fertilizer conservation, and soil reinforcement). Through the evaluation of ecosystem value, the value would reflect the impact of various kinds of park planning on the environmental elements of the park. In general, there is an interaction between planning and value evaluation, and the planning of an urban wetland park can affect the ecosystem services value of parks, and the value of ecosystem services can reflect the impact of planning on a regional ecological environment.

In the planning of the park, the evaluation of the ecosystem value should be made after the planning of the park and before the construction of the site, so that the planning decision-maker can fully understand the impact of different layouts of the plan on the ecological value of the whole wetland. For wetland parks, especially urban wetland parks, due to the close relationship between parks and urban residents, more attention should be paid in preliminary planning to comparing the relationship between the natural and social values, guiding planners to sort out the relationship between the two aspects.

In reality, there is a clear lack of such a step in current park planning in China, taking into account the value of the ecosystem in the park planning and in the decisions of environmental protection [3]. Therefore, it is of great practical value to construct a valuation system of ecosystem services for wetland parks. In this study, facing the increasing man-made disturbance in Aha Lake Park and as an important urban water source, there is a strong relationship with urban residents. In future planning we not only need to consider ecosystem service value, but also need to face the comprehensive needs of different interest groups. In the future, park management will require a larger number of questionnaires and field surveys and make use of more intuitive scientific research methods.

\section{Conclusions}

The main objective of this research was to construct a framework system suitable for evaluating the ecosystem value of urban wetland parks and integrate the values of the various wetland ecosystem functions - including all kinds of direct and indirect functions. Through various ecosystem models and methods of value conversion, all kinds of values are quantified, and eventually the overall ecosystem service value of the park is transformed into a fixed market value. More importantly, a complete set of value evaluation models and scientific and objective evaluation results are built around the wetland park, and the conclusions are as follows:

1) Theoretical level, this study is mainly based on Teeb's framework [10], which is tailored to the characteristics of urban wetland parks. The indicators involved in the evaluation are screened from four steps: "structure and process of regional ecosystem," "ecosystem function," "economic and social benefits," and "value." Taking the case of Aha Lake Wetland Park as an example, this method system through three different steps, the social, environmental, and economic values of the park ecosystem are calculated. Compared with other evaluation methods, the evaluation process of this study is based on the analysis of the characteristics of the study area, starting from different perspectives and important ecosystem components to coordinate the most prominent service value in the park.

2) On a practice level, this study explores the comprehensive and specific indicator quantitative evaluation method. Aiming at some important characteristic indexes, the evaluation method has been innovated. On the one hand, the evaluation process combines remote sensing and field observation data with the quantified ecosystem model such as CASA to calculate such indicators as carbon fixation and oxygen release. On the other hand, some important socio-economic indicators 
are quantified through social surveys and value measures. In addition, to make the evaluation results more objective, this research transforms all kinds of ES values into market values.

3) On a realistic level, the important goal of this study is to set the framework system to make the evaluation process more flexible, to be adjusted based on the characteristics of different regions and reflect the practical features of this study. The study hopes that through the case of Aha Lake Wetland Park, it shows how the specific characteristics of the park can be reflected in the adjustment of the framework and selection of indicators so that the final evaluation results can objectively reflect the important ecosystem features of the park. On the other hand, it discusses the relationship between park planning process and ecosystem service function evaluation, summing up the value of the importance of evaluation. In general, the evaluation of ecosystem service function value plays a role as a bridge between planning scenarios and actual ecosystem functions, and should be fully studied in the management of parks.

\section{Acknowledgements}

This research was partially supported by the National Geographic Air and Water Conservation Fund (grant GEFC29-16).

\section{Conflict of Interest}

The authors declare no conflict of interest.

\section{References}

1. COSTANZA R. Nature: ecosystems without commodifying them. NATURE. 443 (7113), 749, 750, 2006.

2. CHEN L, MOU Z, QIN H, QUN SU. Study on Ecological Service Function and Its Radiation Effect of Wetland Ecosystem. ENVIRON SCI TECHNOL., 2017.

3. MENG W, HE M, HU B, MO X, LI H, LIU B, WANG Z. Status of wetlands in China: A review of extent, degradation, issues and recommendations for improvement. OCEAN COAST MANAGE. 146, 50, 2017.

4. WONG C.P., JIANG B., BOHN T.J., LEE K.N., LETTENMAIER D.P., MA D., OUYANG Z. Lake and wetland ecosystem services measuring water storage and local climate regulation. WATER RESOUR RES. 53 (4), 2017.

5. THEVS N., BECKMANN V., AKIMALIEVA A., KÖBBING J.F., NURTAZIN S., HIRSCHELMANN S., PIECHOTTKA T., SALMURZAULI R., BAIBAGYSOV A. Assessment of ecosystem services of the wetlands in the Ili River Delta, Kazakhstan. ENVIRON EARTH SCI. 76 (1), 30, 2017.

6. AUCOUR A.M., BEDELL J.P., QUEYRON M., THOLÉ R., LAMBOUX A., SARRET G. Zn speciation and stable isotope fractionation in a contaminated urban wetland soil-
Typha latifolia system. ENVIRON SCI TECHNOL. 51 (15), 8350, 2017.

7. RAWLINS J.M., LANGE W.J.D., FRASER G.C.G. An Ecosystem Service Value Chain Analysis Framework: A Conceptual Paper. ECOL ECON. 147, 84, 2018.

8. POTSCHIN M.B., HAINESYOUNG R.H. Ecosystem services: Exploring a geographical perspective. PROG PHYS GEOG. 35 (5), 575, 2011.

9. LIU H., LI F., LI J., ZHANG Y. The relationships between urban parks, residents' physical activity, and mental health benefits: A case study from Beijing, China. J ENVIRON MANAGE. 190, 223, 2017.

10. TEEB. The Economics of Ecosystems and Biodiversity: The Ecological and Economic Foundations (TEEB D0)., 2010.

11. HAUSKNOST D., GRIMA N., SINGH S.J. The political dimensions of Payments for Ecosystem Services (PES): Cascade or stairway? ECOL ECON. 131, 109, 2017.

12. CLARE D., THOMPSON J.R., NATHALIE P. The quest for a mechanistic understanding of biodiversity-ecosystem services relationships. Proceedings of the Royal Society B Biological Sciences. 282 (1817), 20151348, 2015.

13. TEEB. Challenges in framing the economics of ecosystems and biodiversity: the TEEB initiative. CURR OPIN ENV SUST. 2 (1), 15, 2010.

14. ANDERSSON-SKÖLD Y., KLINGBERG J., GUNNARSSON B., CULLINANE K., GUSTAFSSON I., HEDBLOM M., KNEZ I., LINDBERG F., ODE S.Å., PLEIJEL H. A framework for assessing urban greenery's effects and valuing its ecosystem services. J ENVIRON MANAGE. 205, 274, 2018.

15. BARTH N.C., DÖLL P. Assessing the ecosystem service flood protection of a riparian forest by applying a cascade approach. ECOSYST SERV. 21, 39, 2016.

16. FEDELE G., LOCATELLI B., DJOUDI H. Mechanisms mediating the contribution of ecosystem services to human well-being and resilience. ECOSYST SERV. 28A, 43, 2017.

17. CHEN L., SUI X., WANG D., YIN X., JI G. The ecological benefit-loss evaluation in a riverine wetland for hydropower projects - A case study of Xiaolangdi reservoir in the Yellow River, China. ECOL ENG. 96, 34, 2016.

18. ROEBELING P., ABRANTES N., RIBEIRO S., ALMEIDA P. Estimating cultural benefits from surface water status improvements in freshwater wetland ecosystems. SCI TOTAL ENVIRON. s 545-546, 219, 2016.

19. MASI F., RIZZO A., BRESCIANI R., CONTE G. Constructed wetlands for combined sewer overflow treatment: Ecosystem services at Gorla Maggiore, Italy. ECOL ENG., 2016.

20. HAINESYOUNG R., POTSCHIN M. Ecosystem Ecology: The links between biodiversity, ecosystem services and human well-being., 2010.

21. MA MEA. Millennium Ecosystem Assessment, 2005. Ecosystems and Human Well-being: Synthesis., 2005.

22. LI X., JIA Q., LIU J. Seasonal variations in heat and carbon dioxide fluxes observed over a reed wetland in northeast China. ATMOS ENVIRON. 127, 6, 2016.

23. WINTERBOURN C.C., KETTLE A.J., HAMPTON M.B. Reactive Oxygen Species and Neutrophil Function. ANNU REV BIOCHEM. 85 (1), 765, 2016.

24. LIU G., SUN J., TIAN K., XIAO D., YUAN X. Longterm responses of leaf litter decomposition to temperature, litter quality and litter mixing in plateau wetlands. FRESHWATER BIOL. 62 (1), 2017. 
25. SHRESTHA M., SHRESTHA S., DATTA A. Assessment of Climate Change Impact on Water Diversion from the Bago River to the Moeyingyi Wetland, Myanmar. CURR SCI INDIA. 112 (2), 377, 2017.

26. ABE K., KOMADA M., OOKUMA A., ITAHASHI S., BANZAI K. Purification performance of a shallow freewater-surface constructed wetland receiving secondary effluent for about 5 years. ECOL ENG. 69 (4), 126, 2014.

27. LUO X., CHEN L., ZHENG H., CHANG J., WANG H., WANG Z., XING B. Biochar addition reduced net $\mathrm{N}$ mineralization of a coastal wetland soil in the Yellow River Delta, China. GEODERMA. 282, 120, 2016.

28. XIANG S., SHU X., ZHU X.J., ZHU X.D., LI YF., LI B.L. A new indices system for evaluating ecological-economicsocial performances of wetland restorations and its application to Taihu Lake Basin, China. ECOL MODEL. 295, 216, 2015.

29. GAO C., SHI T., LIU D., ZHOU Y., SONG L. The carbon fixation and oxygen release benefits of urban parks' vegetation in Shenyang by adopting GIS with RS., 527, 2011.

30. FIELD C.B., BEHRENFELD M.J., RANDERSON J.T., FALKOWSKI P. Primary production of the biosphere: integrating terrestrial and oceanic components. SCIENCE. 281 (5374), 237, 1998.

31. LIN X., CAI X., WANG J., MEI Z., DAI L. Study on Wetland Spatial and Temporal Patterns of Net Primary Productivity in the Duration of 2000-2010 in Guizhou. ENVIRON SCI TECHNOL., 2015.

32. POTTER C.S., RANDERSON J.T., FIELD C.B., MATSON P.A., VITOUSEK P.M., MOONEY H.A., KLOOSTER S.A. Terrestrial ecosystem production: A process model based on global satellite and surface data. GLOBAL BIOGEOCHEM CY. 7 (4), 811, 1993.

33. HAO H., YAOZHONG P., WENQUAN Z., XULONG L., QING Z., XIUFANG Z. Measurement of terrestrial ecosystem service value in China. CHINESE JOURNAL OF APPLIED ECOLOGY. 16 (6), 1122, 2005.

34. KICKLIGHTER D.W., BONDEAU A., SCHLOSS A.L., KADUK J., MCGUIRE A.D. Comparing global models of terrestrial net primary productivity (NPP): global pattern and differentiation by major biomes. GLOBAL CHANGE BIOL. 5 (S1), 16, 1999.
35. WANG S., ZHANG Y., WEI H., ZHANG H. The NPP Change and the Vegetation Carbon Fixation/Oxygen Release Values in Shaanxi-Gansu-Ningxia Region of China. Journal of Desert Research., 2015.

36. GÓMEZ-BAGGETHUN E., BARTON D.N. Classifying and valuing ecosystem services for urban planning. ECOL ECON. 86 (1), 235, 2013.

37. ZHANG L., ZHAO J., CUI N., DAI Y., KONG L., WU J., CHENG S. Enhancing the water purification efficiency of a floating treatment wetland using a biofilm carrier. Environmental Science \& Pollution Research International. 23 (8), 7437, 2016.

38. GONZALEZ-OLLAURI A., MICKOVSKI SB. Plant-soil reinforcement response under different soil hydrological regimes. GEODERMA. 285, 141, 2017.

39. MAYER M., WOLTERING M. Assessing and valuing the recreational ecosystem services of Germany's national parks using travel cost models. ECOSYST SERV., 2018.

40. DAVIS R.K. Recreation Planning as an Economic Problem. Nat.resources J. 3 (2), 239, 1963.

41. YUE Y.U., BINGYU H.E. Estimation of the non-tratable value of Xinjang Tianchi wetland ecosystem service function bassced on the CVM. Journal of Arid Land Resources \& Environment. 26 (12), 53, 2012.

42. TROLLIET F., SERCKX A., FORGET P.M., BEUDELS-JAMAR R.C., HUYNEN M.C., HAMBUCKERS A. Ecosystem services provided by a large endangered primate in a forest-savanna mosaic landscape. BIOL CONSERV. 203, 55, 2016.

43. COSTANZA R., FARBER S.C., MAXWELL J. Valuation and management of wetland ecosystems. ECOL ECON. 1 (4), 335, 2006.

44. VERMAAT J.E., WAGTENDONK A.J., BROUWER R., SHEREMET O., ANSINK E., BROCKHOFF T., PLUG M., HELLSTEN S., AROVIITA J., TYLEC L. Assessing the societal benefits of river restoration using the ecosystem services approach. HYDROBIOLOGIA. 769 (1), 121, 2016.

45. ZHUANG C., OUYANG Z., XU W., BAI Y., ZHOU W., ZHENG H., WANG X. Impacts of human activities on the hydrology of Baiyangdian Lake, China. ENVIRON EARTH SCI. 62 (7), 1343, 2011. 